\title{
Development and Characterization of Voriconazole Loaded In Situ Gel Formulations for Ophthalmic Application
}

\author{
Oküler Uygulama için Vorikonazol Yüklü In Situ Jel Formülasyonlarının \\ Geliștirilmesi ve Karakterizasyonu
}

Neslihan ÜSTÜNDAĞ OKUR ${ }^{*}$, Ayșegül YOLTAȘ², Vildan YOZGATLI1

1'istanbul Medipol University, Faculty of Pharmacy, Department of Pharmaceutical Technology, Beykoz, 34810, İstanbul, TURKEY

2Ege University, Faculty of Science, Department of Biology, Fundamental and Industrial Microbiology Division, Bornova, 35100, Izmir, TURKEY

\begin{abstract}
The aim of the this research was to prepare and evaluate the potential use of in situ gel formulations for ocular delivery of voriconazole for the treatment of fungal keratitis. An in situ gelling system was used to increase the residence time and thus the bioavailability of voriconazole in ocular mucosa. Temperature triggered in situ gel formulations were prepared by cold method using polymers like poloxamer 188, poloxamer 407 and sodium alginate. Finally, concentration of voriconazole in formulations was $0.1 \%(\mathrm{w} / \mathrm{w})$. These formulations were evaluated for clarity, sol-gel transition temperature, gelling capacity, $\mathrm{pH}$, viscosity and drug content. The gelation temperatures of all the formulations were within the range of $32-34^{\circ} \mathrm{C}$. All the formulations exhibited fairly uniform drug content. Furthermore in vitro drug release and antifungal activity of these formulations were also evaluated. Drug release study of all the formulations showed sustained release properties. In conclusion, voriconazole loaded in situ gels could be offered as a promising strategy for ocular drug delivery for the treatment of fungal keratitis.

Key words: Voriconazole, In situ gel, Ocular drug delivery, Characterization, Microbiological study
\end{abstract}

\section{öz}

Bu araştırmanın amacı fungal keratit tedavisi için vorikonazolün göze hedeflendirilmiş potansiyel kullanımı olan in situ jel formülasyonlarını hazırlamak ve değerlendirmektir. In situ jelleştirici sistemi vorikonazolün oküler mukozada kalış süresini dolayısıyla biyoyararlanımını arttırmak için kullanılmıștır. Sıcaklıktan etkilenen in situ jel formülasyonları poloksamer 188, poloksamer 407 ve sodyum alginat gibi polimerler kullanılarak soğuk yöntemle hazırlanmıştır. Son olarak, formülasyonların içindeki vorikonazol konsantrasyonu \%0.1 (a/a)dir. Bu formülasyonlar berraklık, sol-jel geçiș sıcaklığı, jelleșme kapasitesi, pH, viskozite ve ilaç içeriği açısından değerlendirilmiştir. Bütün formülasyonların jelleșme sıcaklığı $32-34^{\circ} \mathrm{C}$ arasında değişmektedir. Bütün formülasyonlar oldukça uygun ilaç içeriğini göstermiştir. Ayrıca bu formülasyonların in vitro ilaç salımı ve antifungal aktivitesi de değerlendirilmiştir. Bütün formülasyonların ilaç salım çalıșması sürekli salım özelliği göstermiştir. Sonuç olarak, vorikonazol yüklü in situ jeller fungal keratit tedavisinde göze ilaç hedeflendirilmesi için gelecek vadeden bir strateji olarak sunulabilir.

Anahtar kelimeler: Vorikonazol, In situ jel, Oküler ilaç dağııımı, Karakterizasyon, Mikrobiyolojik çalışma

\section{INTRODUCTION}

The eye is unique in terms of its anatomical and physiological nature and defence mechanisms, which make the targeting of drugs to eye tissues one of the greatest challenges in drug delivery $(1,2)$. One of the major limitations faced in ophthalmic delivery is the attainment and retention of optimum drug concentration at the site of action within the eye $(3,4,5)$. Poor bioavailability of drugs from conventional ocular dosage forms in mainly due to tear production, nasolacrimal drainage and transient residence time, drainage of the instilled solution, tear turnover and limited corneal area
(6). Various ophthalmic vehicles such as inserts, ointments, suspensions and aqueous gels, have been developed in order to lengthen the residence time of instilled dose and enhance the ophthalmic bioavailability. These ocular drug delivery systems, however, have not been used extensively because of some drawbacks such as blurred vision from ointments or lack of patient compliance are the main reasons that they have not universally accepted $(6,8,9)$. The effective dose administered may be altered by increasing the retention time of medication into the eye by using in situ gel forming systems (10). In situ gel forming systems are liquid aqueous solutions 
before administration but turn to gel under physiological conditions. There are several possible mechanisms that lead to in situ gel formation, such as $\mathrm{pH}$ change, ionic crosslinkage, and temperature modulation $(11,12)$.

Several in situ gel forming systems have been developed to prolong the precorneal residence time of a drug and improve ocular bioavailability. Polymers are employed in such delivery systems to carry various drugs and they may demonstrate a transition from sol(liquid) to gel state once instilled in the culde-sac of the eye (13). In situ gel forming formulations current a novel idea of deliver drugs to patients as a liquid dosage form, yet achieve sustained release of drug for the desired period. Different delivery systems based on polymers have been developed, which are able to increase the residence time of the formulation at absorption site of drugs. In recent years, there has been an increasing interest in water-soluble polymers are highly advantageous compared with other polymers because, in contrast to very strong gels, they can be easily applied in liquid form to the site of drug absorption. At the site of drug absorption, they swell to form a strong gel that is capable of prolonging the residence time of drug (14).

Keratitis, a disease of the cornea, results from direct infection with viruses, bacteria, fungi, yeast, and amoebae or from immune-related complications (4). Fungal keratitis is a leading cause of serious ocular morbidity and blindness. It is worldwide in distribution, but is more common in the tropics and subtropical regions. In fungal keratitis, early diagnosis and antifungal therapy is necessary in preventing further

Table 1. Poloxamers concentrations, gelling temperature and $\mathrm{pH}$ of the formulations

\begin{tabular}{|c|c|c|c|c|}
\hline Codes & $\begin{array}{l}\text { Poloxamer } \\
407 \text { (\%) }\end{array}$ & $\begin{array}{l}\text { Poloxamer } \\
188(\%)\end{array}$ & $\begin{array}{l}\text { Gelling temperature } \\
\left({ }^{\circ} \mathrm{C}\right)\end{array}$ & $\mathrm{pH}$ \\
\hline F1 & 15 & 10 & $42-43$ & 7.15 \\
\hline $\mathrm{F} 2$ & 15 & 15 & $39-40$ & 7.31 \\
\hline F3 & 15 & 20 & $35-36$ & 7.44 \\
\hline F4 & 15 & 23 & $34-35$ & 7.53 \\
\hline F5 & 15 & 25 & $30-32$ & 7.63 \\
\hline F6 & 18 & 15 & $41-42$ & 7.51 \\
\hline F7 & 18 & 18 & $38-39$ & 7.57 \\
\hline F8 & 18 & 20 & $33-34$ & 7.53 \\
\hline F9 & 18 & 22 & $32-33$ & 7.63 \\
\hline F10 & 18 & 25 & $28-29$ & 7.85 \\
\hline F11 & 20 & 5 & $30-32$ & 7.07 \\
\hline F12 & 20 & 10 & $33-34$ & 7.22 \\
\hline F13 & 20 & 15 & $36-37$ & 7.30 \\
\hline F14 & 20 & 20 & $32-33$ & 7.34 \\
\hline F15 & 20 & 23 & $32-33$ & 7.67 \\
\hline
\end{tabular}

complications such as hypopyon formation, endophthalmitis, or loss of vision (15).

Voriconazole (VCZ), $\mathrm{C}_{16} \mathrm{H}_{14} \mathrm{~F}_{3} \mathrm{~N}_{5} \mathrm{O}$, a second generation antifungal agent possesses phenomenal characteristics like broad-spectrum activity, activity against resistant fungal species, and acceptable tolerability. Almost $100 \%$ in vitro susceptibility was observed against various fungal isolates associated with keratitis and endophthalmitis. Moreover, studies suggested an excellent efficacy of voriconazole against several ocular mycoses following topical administration (16).

In this study, a new ocular drug delivery system based on the dispersion of voriconazole loaded in situ gels coating into sodium alginate was proposed. The characterization properties of the system were investigated, including clarity, gelling capasity, $\mathrm{pH}$, viscosity and drug content. In vitro drug release and antifungal activity of these formulations were also evaluated.

\section{EXPERIMENTAL}

\section{Materials}

VCZ and sodium alginate were purchased from Sigma, Germany. Poloxamer 407 and poloxamer 188 were kind gift from BASF, Turkey. Distilled water was used throughout the study. High pressure liquid chromatography (HPLC) grade acetonitrile (Sigma, Germany) was used for HPLC studies. Roswell Park Memorial Institute (RPMI 1640) medium was puchased from Sigma-Aldrich, Germany (R65504). All the other chemicals and solvents were of analytical or HPLC grade. Dialysis membrane (Spectro/por Dialysis Mebrane, Spectra/por 4, diameter $16 \mathrm{~mm}$, molecular weight of 12-14 $\mathrm{kDa}$ ) was purchased from Spectrum.

\section{Preparation of in situ gel formulations}

Poloxamer analogs were used as the gelling agents, and the in situ gels were prepared by using a cold method (17). The polymeric solutions were prepared by dispersing required quantity of Poloxamer 407 and Poloxamer 188 in cold water $\left(5^{\circ} \mathrm{C}\right)$ using a magnetic stirrer until the poloxamer completely dissolve (approximately 2 hours). The dispersion was kept in a refrigerator for 48 hours to get clear solution.

\section{Determination of sol-gel temperature (Tsol-gel)}

$20 \mathrm{~g}$ of cold sample solution were put into a beaker and placed in a temperature-controlled stirrer. A thermometer was immersed into the sample solution for constant monitoring. The solution was heated at the rate of $2{ }^{\circ} \mathrm{C} / \mathrm{min}$ with the continuous with stirring at $200 \mathrm{rpm}$. The temperature at which the magnetic bar stopped moving due to gelation was reported as the gelation temperature. The maximum limit for gelation was checked up to $60{ }^{\circ} \mathrm{C}$. Optimum poloxamer ratios were determined and selected with sol-gel temperature as $32-34{ }^{\circ} \mathrm{C}$ which is the eye surface temperature (18). The experiments were repeated four times. 


\section{Preparation of voriconazole loaded in situ gel formulations}

In situ gels were selected according to $\mathrm{pH}$ values and gelling temperatures of formulations. F11 (ratio of P407 and P188 were $20 \%$ and $5 \%$, respectively) was selected as optimum formulation for preparation an ocular formulation. After detection of the optimum in situ gel compositions sodium alginate of different concentrations $(0.1 \%, 0.3 \%$, and $0.5 \%$ ) and for each formulations same concentration of VCZ were added in poloxamer solutions with continuous stirring until completely dissolved. Benzalkonium chloride $(0.02 \% \mathrm{w} / \mathrm{w})$ was added as a preservative to the solutions. Sufficient amount of sodium chloride $(0.9 \% \mathrm{w} / \mathrm{w})$ was added to the mixture to maintain the isotonicity. The effect of drug and the other compositions of formulations on gel temperature were also evaluated.

\section{Characterization of in situ gels}

The prepared ocular formulations were characterized such as clarity, gelling capacity, $\mathrm{pH}$, viscosity and drug content. In addition gelling temperature of formulations was determined and statistical analysis was performed using t-test. Data were considered statistically significant at $p<0.05$. The experiments were repeated four times.

\section{Clarity of formulations}

The clarity of formulations was determined by visual inspection under black and white background, and it was graded as follows: turbid, +; clear, ++; and very clear (glassy), +++ .

\section{Gelling capacity}

The gelling capacity of the prepared formulation was determined by placing a drop of the formulation in a beaker at $32-34^{\circ} \mathrm{C}$ and it was visually observed for gelling time. It was graded as follows: +; gel after few minutes dissolves rapidly, ++ immediate gelation remains for few mins, +++; immediate gelation remains for nearly an hour.

\section{Determination of $\mathrm{pH}$}

The $\mathrm{pH}$ of the gel was determined using calibrated $\mathrm{pH}$ meter (Mettler Toledo, Switzerland). Determinations were carried out four times and an average of these determinations was taken as the $\mathrm{pH}$ of the prepared gels.

\section{Determination of viscosity}

The viscosity of the developed formulations was performed with a digital viscometer (Brookfield) equipped with spindle RV2 with $50 \mathrm{rpm}$ at $32 \pm 2^{\circ} \mathrm{C}$.

\section{Drug content}

$1 \mathrm{~mL}$ of the developed in situ gel formulation was dissolved in $100 \mathrm{~mL} \mathrm{pH} 7.4$ simulated tear fluid buffer ( $\mathrm{NaCl}$ : 0.670g, $\mathrm{NaHCO}_{3}: 0.200 \mathrm{~g}, \mathrm{CaCl}_{2} \cdot 2 \mathrm{H}_{2} \mathrm{O}: 0.008 \mathrm{~g}$ and distiled water q.s. to $100 \mathrm{~g}$ ) (19) followed by HPLC estimation of the aliquot to determine drug concentration. The experiments were repeated four times.

\section{HLPC analysis}

The HPLC system consisted of a gradient pump and a UV detector supplied by Agilent 1100. C18 column $(150 \times 4.6 \mathrm{~mm}, 5 \mu \mathrm{m})$ (GL Sciences, Japan) was used. The samples were analyzed at $256 \mathrm{~nm}$ with a $1 \mathrm{~mL} / \mathrm{min}$ flow rate at $25^{\circ} \mathrm{C}$. The mobile phase was a mixture of acetonitrile: ultrapure water (50:50). Retention time of drug was 4.098 min. The method was validated partially linearity, limit of detection (LOD) and limit of quantitation (LOQ), precision, accuracy and specificity, selectivity and stability.

\section{In vitro drug release study}

The in vitro drug release study was performed using the dialysis bag method (5). In vitro release study of in situ gel formulations was carried out in simulated tear fluid $(\mathrm{pH}=7.4)$ at $50 \mathrm{rpm}$. The temperature was maintained at $33 \pm 1^{\circ} \mathrm{C}$ to mimic eye surface temperature. $5 \mathrm{~g}$ formulation was separated from release media by means of dialysis membrane (Spectra/por, MW of 12-14 kDa) and capped with closures. The membrane was heated $33 \pm 1^{\circ} \mathrm{C}$ for $30 \mathrm{~min}$ in bidistilled water before use. $0.5 \mathrm{~mL}$ of sample was withdrawn at a predetermined time interval of $1 \mathrm{~h}$ to $8 \mathrm{~h}$ and the same volume of fresh medium was replaced. The samples were analyzed with HPLC for the drug content. The experiments were repeated three times.

\section{Stability of the in situ gels}

In physical stability studies, VCZ loaded in situ gels were stored at $5 \pm 1^{\circ} \mathrm{C}$ in the refrigerator and $25 \pm 2^{\circ} \mathrm{C}$ and $40 \pm 2^{\circ} \mathrm{C}$ for 3 months in the stability cabinets (Nüve, Turkey). After storage for 3 months visual appearance, clarity, $\mathrm{pH}$, gelation time of in situ gels and VCZ content were investigated. The experiments were repeated three times.

\section{Microbiological studies}

\section{Sterility studies}

In situ gel formulations in the presence or absence of VCZ were prepared at Laminar air flow Cabinet (Haier HR40-IIA2).

To check the sterility of the prepared ocular formulations sterility control testing were performed. Sterility testing of the in situ gel formulations with or without VCZ was carried out under aseptic conditions according to the international pharmacopoeia. For anaerobic bacteria Fluid thioglycollate medium was used. For fungi and aerobic bacteria soya-bean casein digest medium was used. $1 \mathrm{~mL}$ of formulation solution was added to each medium and incubated at $35^{\circ} \mathrm{C}$ for bacteria and $25^{\circ} \mathrm{C}$ for fungi for 14 days.

To check the suitability of the used mediums for the sterility testing promotion test were performed. For growth promotion test of aerobes, anaerobes and fungi, fluid thioglycollate media (using separate portion of media for each microorganism) were inoculated with $100 \mathrm{CFU}$ of Staphylococcus aureus ATCC 6538, Clostridium sporogenes ATCC 19404 and Candida albicans ATCC 10231. Media were incubated at $35^{\circ} \mathrm{C}$ for $48 \mathrm{~h}$. 


\section{Determination of MIC of VCZ}

The broth microdilution test was done in accordance with CLSI guidelines for filamentous fungi (20) and yeasts (21). VCZ was dissolved in dimethyl sulfoxide, final dilutions were made in RPMI 1640 medium buffered to $\mathrm{pH} 7.0$ with 0.165 M MOPS buffer [3-(N-morpholino) propanesulfonic acid] and final concentrations were 500-0.125 $\mu \mathrm{g} / \mathrm{mL}$. Using the spectrophotometric method of inoculum preparation, an inoculum concentration of $1.5( \pm 1.0) \times 10^{3}$ cells $/ \mathrm{mL}$ for yeasts and $0.4-5 \times 10^{4}$ spores $/ \mathrm{mL}$ for moulds, and RPMI 1640 medium buffered with MOPS were used. C. albicans ATCC 10231, C. tropicalis RSKK 2412, A. fumigatus ATCC 204305 and A. flavus ATCC 204304 which may be possible causes of fungal keratitis were used to evaluate antifungal activity of developed formulations (22,23). A $0.1 \mathrm{~mL}$ inoculum was added to each well of the microdilution trays. The MICs were determined after $48 \mathrm{~h}$ of incubation. The plates were shaken before the comparison of growth in wells. With an aid of a reading mirror, growth in each well was compared with the VCZ free growth control well. The MIC endpoints were evaluated for the lowest drug concentration that showed a prominent reduction (50\%) of the growth in the control well.

\section{Disk diffusion testing}

Disk diffusion testing was performed according to CLSI standard M44-A2 for yeasts and M51-A for filamentous fungi. MuellerHinton agar (Difco) supplemented with $2 \%$ glucose and $0.5 \mu \mathrm{g} /$ $\mathrm{mL}$ methylene blue dye (SSI Diagnostica, Hillerød, Denmark) was used. Blank disks that were $12.1 \mathrm{~mm}$ in diameter were impregnated with $20 \mu \mathrm{L}$ of formulations at final concentration of 1 $\mu \mathrm{g} / \mathrm{disk}$ and allowed to dry at room temperature. C. albicans ATCC 10231 and C. tropicalis RSKK 2412, A. fumigatus ATCC 204305 and $A$. flavus ATCC 204304 which may be possible causes of fungal keratitis $(22,23)$ were used to evaluate antifungal activity of developed formulations. The mold inocula were prepared at optical densities ranging from 80 to $82 \%$ and a suspension with a $0.5 \mathrm{McF}$ arland standard was utilized for yeasts. The plates were incubated at $35^{\circ} \mathrm{C}$ and inhibition zone (IZs, in millimeters) diameters were read by using a digital ruler at 24 and $48 \mathrm{~h}$. Minor trailing growth in the inhibition zones was ignored.

\section{RESULTS AND DISCUSSION}

\section{Preparation of in situ gel formulations}

Preliminary studies were carried out using different concentrations of polymers evaluated for their gelling

\section{Table 2. Compositions of the in situ gels (\%)}

\begin{tabular}{llllll} 
Components (\%) & S & S1 & S2 & S3 & S4 \\
\hline Poloxamer 407 & 20 & 20 & 20 & 20 & 20 \\
\hline Poloxamer 188 & 5 & 5 & 5 & 5 & 5 \\
\hline Sodium alginate & - & - & 0.1 & 0.3 & 0.5 \\
\hline Sodium chloride & 0.9 & 0.9 & 0.9 & 0.9 & 0.9 \\
\hline Voriconazole & - & 0.1 & 0.1 & 0.1 & 0.1 \\
\hline Benzalkonium chloride & 0.02 & 0.02 & 0.02 & 0.02 & 0.02 \\
\hline Distiled water qs to & 100 & 100 & 100 & 100 & 100 \\
\hline
\end{tabular}

temperature in order to identify the compositions suitable for use in the in situ gelling system for ocular drug delivery. Temperature sensitive in situ gels were successfully prepared by cold method using poloxamer 407, poloxamer 188 . Cold method is one of the preferred methods due to providing clear solution for in situ gel while hot process causes formation of lumps of polymer as reported and observed in literature (24).

Poloxamer 407 (ethylene oxide and propylene oxide blocks) has excellent thermo-sensitive gelling properties, which is of the most interest in optimising drug formulation. Poloxamer 407 formulations led to enhanced solubilization of poorly water-soluble drugs and prolonged release profile for many applications (e.g., ophthalmic, oral, rectal, topical, nasal and injectable preparations) but did not clearly show any relevant advantages when used alone. Combination with other excipients like Poloxamer 188 or mucoadhesive polymers promotes the action of Poloxamer 407 by optimising sol-gel transition temperature or increasing bioadhesive properties (25). For this purpose poloxamer 188 and poloxamer 407 mixture were used to develop in situ gels.

To find out optimum gelling temperature $\left(32 \pm 2^{\circ} \mathrm{C}\right)$, the poloxamer 407 and poloxamer 188 were mixed various concentrations. Table 1 shows poloxamer concentrations, gelling temperature and $\mathrm{pH}$ of the prepared formulations. F11 was selected optimum composition which contains poloxamer 407 (20\%) and poloxamer 188 (5\%).

After selecting F11 formulation, benzalkonium chloride $(0.02 \%, \mathrm{w} / \mathrm{w})$ was added as a preservative to the solution. Sufficient amount of sodium chloride $(0.9 \% \mathrm{w} / \mathrm{w})$ was added to the mixture to maintain the isotonicity and the formulation was coded as S. $0.1 \%(\mathrm{w} / \mathrm{w})$ VCZ was loaded and different concentrations of sodium alginate of different concentrations $(0.1 \%, 0.3 \%$, and $0.5 \%)$ was added in poloxamer solutions with continuous stirring until completely dissolved. Finally, concentration of VCZ in formulations was $0.1 \%(\mathrm{w} / \mathrm{w})$. The dispersion was kept in a refrigerator for 48 hours to get clear solution. The components of ocular in situ gels in absence or presence of VCZ are shown in Table 2.

\section{Characterization of in situ gels}

Characterization of the new drug delivery systems are major issues to be considered in the formulation stage, especially those intended for ocular administration. The physicochemical characterization parameters of in situ gels are reported in Table 3.

The clarity of all the formulations was found to be satisfactory, as shown in Table 3. Gelation temperature was changed from $32.5^{\circ} \mathrm{C}$ to $34.3^{\circ} \mathrm{C}$ with incorporation of $0.1 \% \mathrm{w} / \mathrm{w} \mathrm{VCZ}$ in the poloxamer solution, while the addition of the mucoadhesive polymers played a reverse role on gelation temperature. The results showed that incorporation of sodium alginate into in situ gel formulation significantly decreased the gelling temperature $(p<0.05)$. When the concentration of 
sodium alginate was increased in the in situ gels, the gelling temperature was decreased (Table 3). Gelling temperature of the all formulations (S, S1-S4) were found between 32$35^{\circ} \mathrm{C}$. This indicates that the formulations can be converting the gel when they installed the eye surface. At $32-34^{\circ} \mathrm{C}$, the solutions are converted into gels with high viscosity. The gelling capacity data of prepared formulations presented in Table 3 represent that the formulations all formulations had immediate gelation and exist for an hour.

The $\mathrm{pH}$ of an ophthalmic formulation is important for patient compliance. The $\mathrm{pH}$ of the prepared formulations ranged between 7.07 and 7.13. The $\mathrm{pH}$ of the formulations was appropriate for ocular delivery since they were iso-hydric. This indicated the nonirritancy of the formulation in ocular mucosa. When a formulation is administered to the eye, it stimulates the flow of tears. Tear fluid is capable of quickly diluting and buffering small volumes of added substances, thus eye can tolerate a fairly wide $\mathrm{pH}$ range. Ophthalmic solutions may range from 6.5 to $8.5(26,27)$.

The formulation should have an optimum viscosity, which will allow its instillation into the eye as a liquid, which will then undergo rapid sol-gel transition due to temperature change. When the in situ solutions were installed the $32-34^{\circ} \mathrm{C}$ surface, the solutions were converted to gel form after few seconds.

All the formulations reflected fairly uniform drug content ensuring adequacy in the method of preparation of the in situ gel. Drug content was found to be within the range of 82.68 $92.58 \%$. The drug content of the prepared formulations was within acceptable limits and ensured dose uniformity.

\section{In vitro drug release study}

The in situ gelling formulations of VCZ, S1-S4, were subjected to in vitro release studies, which were carried out using simulated tear fluid of $\mathrm{pH} 7.4$ as release medium. Formulations showed sustained drug release for a period of 8 hours (Figure 1). At the end of the $8 \mathrm{~h}$, in vitro VCZ release from S1, S2 and S3 formulations was found as 63\%, 60\% and $60 \%$, respectively ( $p>0.05)$. S4 formulation was showed slower release than the other formulations. This could be the reason of higher concentration of sodium alginate among the developed formulations. Mandal et al. prepared moxifloxacin hydrochloride loaded in situ gel using sodium alginate and hydroxy propyl methyl cellulose as polymers. They were found that when sodium alginate and hydroxy propyl methyl cellulose concentration was increased, release rate was decreased (28).

\section{Stability}

The stability studies were carried out at $5 \pm 1^{\circ} \mathrm{C}, 25 \pm 2^{\circ} \mathrm{C}$ and $40 \pm 2^{\circ} \mathrm{C}$ for 3 month using stability cabinets. The samples were analyzed periodically on every month, and found that there are no changes in visual appearance, clarity, and gelation time. After 3 month pH values of S1, S2 S3 and S4 formulations were found as $7.12 \pm 0.002,7.18 \pm 0.001,7.20 \pm 0.001$ and $7.21 \pm 0.002$, respectively. In addition $92-98 \%$ of initial drug content of formulations was kept its stability for in 3 month.

\section{Microbiological studies}

The optimized in situ gels passed the test for sterility as there was no appearance of turbidity and hence no evidence of microbial growth when incubated for 14 days at $35^{\circ} \mathrm{C}$ in case of fluid thioglycolate medium and at $20-25^{\circ} \mathrm{C}$ in the case of soyabean casein digest medium. Furthermore to control the used

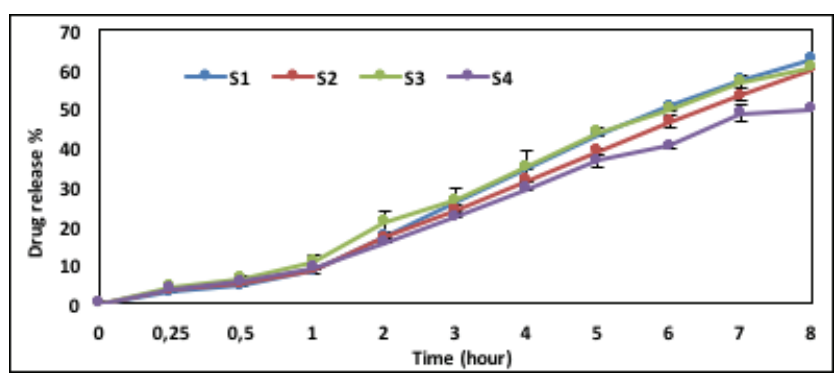

Figure 1. In vitro release of voriconazole from in situ gels at $\mathrm{pH} 7.4$ simulated tear fluid buffer

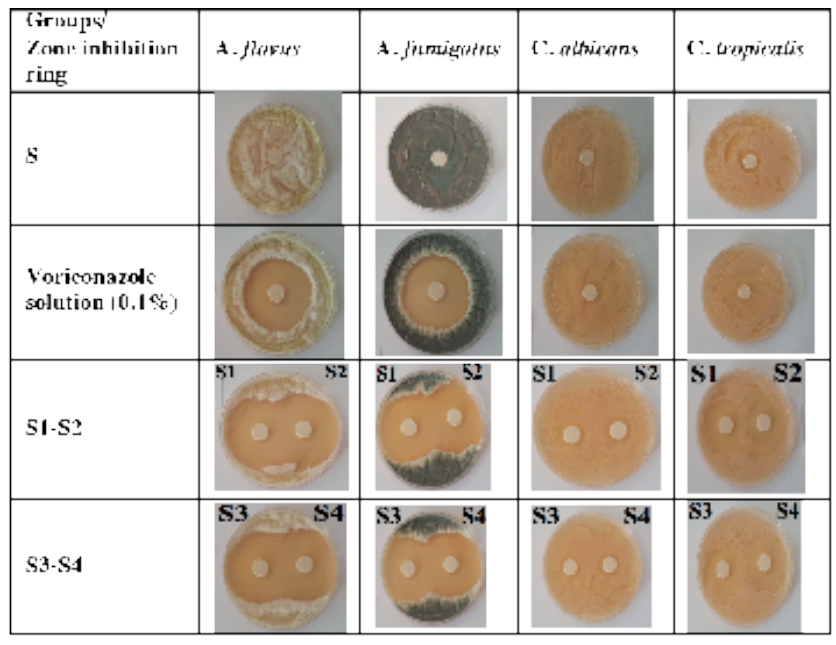

Figure 2. Zone inhibition diameters of formulations against $A$. flavus, $A$. fumigatus, C. albicans and C. tropicalis

Table 3. Clarity, gelling temperature, pH, drug content, in vitro gelation capacity, viscosity, and drug content of in situ gels

\begin{tabular}{|c|c|c|c|c|c|}
\hline Formulations & $S$ & S1 & $\mathrm{S} 2$ & S3 & S4 \\
\hline Clarity & +++ & +++ & +++ & ++ & ++ \\
\hline Gelling temperature (oC) & $32.5 \pm 0.03$ & $34.3 \pm 0.01$ & $33.1 \pm 0.023$ & $32.6 \pm 0.012$ & $32.4 \pm 0.001$ \\
\hline Gelling capacity & +++ & +++ & +++ & +++ & +++ \\
\hline $\mathrm{pH}$ & $7.07 \pm 0.002$ & $7.08 \pm 0.001$ & $7.1 \pm 0.002$ & $7.11 \pm 0.001$ & $7.13 \pm 0.001$ \\
\hline Drug content (\%) & - & $83.14 \pm 0.36$ & $82.68 \pm 1.06$ & $84.11 \pm 0.7$ & $92.58 \pm 0.35$ \\
\hline
\end{tabular}


mediums for suitability of sterility test growth promotion test were performed and it was found that both microorganisms showed visible growth in all media.

The MIC endpoints were evaluated for the lowest drug concentration that showed a prominent reduction $(90 \%$ and $50 \%$ ) of the growth in the control well. MIC $_{90}$ values of VCZ against $C$. albicans, $C$. tropicalis, $A$. fumigatus and $A$. flavus were $2,1,0.5$ and $0.5 \mu \mathrm{g} / \mathrm{mL}$, respectively and $\mathrm{MIC}_{50}$ values were $0.25 \mu \mathrm{g} / \mathrm{mL}$ for all of the microorganisms. In accordance with our study (29) also evaluated the $\mathrm{MIC}_{90}$ results in Aspergillus $s p$. as $1 \mathrm{mg} / \mathrm{L}$. (30) determined the MIC values for both clinical and environmental strains of $A$. fumigatus and $A$. flavus and the $\mathrm{MIC}$ ranges were $0.25-2 \mu \mathrm{g} / \mathrm{mL}$ for both of the microorganisms and (31) MIC ranges of $A$. fumigatus and $A$. flavus isolates were 0.25-1 and 0.125-1 $\mu \mathrm{g} / \mathrm{mL}$, respectively. For Candida species according to CLSI M27-A3 MIC values $\leq 1 \mu \mathrm{g} / \mathrm{mL}$ are accepted as susceptible; $2 \mu \mathrm{g} / \mathrm{mL}$ are dose dependent susceptible and $\geq 4 \mu \mathrm{g} / \mathrm{mL}$ are accepted as resistant.

The efficacy of groups was investigated using the inhibition zone diameters in disc diffusion test. Disk diffusion testing was performed according to CLSI standard M44-A2 for yeasts and M51-A for filamentous fungi. C. albicans, C. tropicalis, $A$. fumigatus and $A$. flavus were used as they are the common organisms causing ocular fungal infections $(22,23)$. Figure 2 shows inhibition zone (IZ) diameters of formulations. The developed VCZ loaded in situ gels were found to be more effective on more effective on moulds in comparison with yeasts (A. flavus than $C$. albicans) (Table 4). In addition to this, sodium alginate is not effective on the $C$. albicans, $C$. tropicalis, $A$. fumigatus and $A$. flavus, because addition of sodium alginate into the in situ gel (S1) did not changed the IZ diameter. While absence of voriconazole ( $\mathrm{S}$ ) in the in situ gel (blank in situ gel) is not effective on C. albicans, $A$. fumigatus and A. flavus; a minor inhibition zone was seen in $C$. tropicalis which may be caused by benzalkonium chloride $(0.02 \%, w / w)$ or other components of the gel. Since the interpretive breakpoints of VCZ for susceptible species is $\geq 17 \mathrm{~mm}$ and for resistant is $\leq 13$ $\mathrm{mm}$, we can say that all of organisms are susceptible for all of the formulations (32).

\section{CONCLUSION}

In the present study, the potential of VCZ loaded in situ gels as drug carriers for ocular delivery was investigated. The

\section{Table 4. Zone inhibition diameters of formulations}

Groups/

Inhibition Zone A.flavus A.fumigatus $\quad$ C. albicans $\quad$ C. tropicalis (IZ) $(\mathrm{cm} \pm S D)$

\begin{tabular}{lllll}
\hline S & $0 \pm 0$ & $0 \pm 0$ & $0 \pm 0$ & $2.0 \pm 0.1$ \\
\hline S1 & $5.7 \pm 0.5$ & $4.8 \pm 0.3$ & $2.1 \pm 0.2$ & $3.1 \pm 0.1$ \\
\hline S2 & $5.2 \pm 0.4$ & $5.0 \pm 0.3$ & $2.0 \pm 0.1$ & $2.8 \pm 0.3$ \\
\hline S3 & $5.8 \pm 0.1$ & $4.9 \pm 0.2$ & $1.9 \pm 0.1$ & $3.3 \pm 0.1$ \\
\hline S4 & $5.1 \pm 0.3$ & $5.0 \pm 0.5$ & $2.1 \pm 0.1$ & $3.4 \pm 0.2$ \\
\hline
\end{tabular}

present study showed that in situ gels of VCZ can successfully be prepared with cold method. The clarity, $\mathrm{pH}$, gellation time and drug content of all formulations was found to be satisfactory. In addition the formulations were found stable for 3 month. Further, all the formulations showed sustained drug release for a period of $8 \mathrm{~h}$, which satisfied to treat ocular disease. The developed in situ gels showed anti fungal activiy on $C$. albicans, $C$. tropicalis, A. fumigatus and $A$. flavus. In conclusion, this study showed that developed in situ gel formulations could be alternatively used as ocular delivery of voriconazole. The present study can open up a window for opthalmic application of in situ gels loaded with VCZ, they would be a better alternative to conventional eye drops in the treatment of fungal keratitis of the eye.

\section{Declaration of Interest}

The authors declare no conflict of interest.

\section{REFERENCES}

1. Almeida H, Amaral MH, Lobão P, Lobo JM. In situ gelling systems: a strategy to improve the bioavailability of ophthalmic pharmaceutical formulations. Drug Discov Today 19, 400-412, 2014.

2. Üstündağ-Okur N, Homan-Gökçe E. Lipid nanoparticles for ocular drug delivery. Int J Ophthalmic Res 1(3), 77-82, 2015.

3. Makwana SB, Patel VA, Parmar SJ. Development and characterization of in-situ gel for ophthalmic formulation containing ciprofloxacin hydrochloride. Results Pharma Sci, doi:10.1016/j.rinphs.2015.06.001, 2015.

4. Üstündağ-Okur N, Gökçe EH, Boybıyık DI, Eğrilmez S, Ertan G, Özer Ö. Novel nanostructured lipid carrier based inserts for controlled ocular drug delivery: Evaluation of corneal bioavailability and treatment efficacy on bacterial keratitis. Expert Opin Drug Deliv 12(11), 1-17, 2015.

5. Üstündağ-Okur N, Gökçe EH, Eğrilmez S, Özer Ö, Ertan G. Novel ofloxacin-loaded microemulsion formulations for ocular delivery. J Ocul Pharmacol Ther 30(4), 319-332, 2014.

6. Swapnil D, Sonawane, Lahoti S. Design and evaluation of ion induced in situ gel formulation for levofloxacin hemihydrateocular delivery. Int J Pharm Sci Invent 3, 38-43, 2014.

7. Darwhekar G, Jain P, Jain DK, Agrawal G. Development and optimization of dorzolamide hydrochloride and timolol maleate in situ gel for glaucoma treatment. Asian J Pharm 1, 93-97, 2011.

8. Jung JH, Abou-Jaoude M, Carbia BE, Plummer C, Chauhan A. Glaucoma therapy by extended release of timolol from nanoparticle loaded silicone hydrogel contact lenses. J Control Release 165, 8289, 2013.

9. Gallarate M, Chirio D, Bussano R, Peira E, Battaglia L, Baratta F, Trotta M. Development of $\mathrm{O} / \mathrm{W}$ nanoemulsions for ophthalmic administration of timolol. Int J Pharm 440, 126-134, 2013.

10. Mandal S, Thimmasetty MKMJ, Geetha MS. Formulation and evaluation of an in situ gel-forming ophthalmic formulation of moxifloxacin hydrochloride. Int J Pharm Investig 2(2), 78-82, 2012.

11. Hosny KM. Preparation and evaluation of thermosensitive liposomal hydrogel for enhanced transcorneal permeation of ofloxacin. AAPS PharmSciTech 10, 1336-1342, 2009. 
12. Hosny KM, Hassan AH. Intranasal in situ gel loaded with saquinavir mesylate nanosized microemulsion: Preparation, characterization, and in vivo evaluation. Int J Pharm 475(1-2), 191-197, 2014.

13. Varshosaz J, Tabbakhian M, Salmani Z. Designing of a thermosensitive chitosan/poloxamer in situ gel for ocular delivery of ciprofloxacin. TODDJ 2, 61-67, 2008.

14. Garala K, Joshi P, Patel J. Formulation and evaluation of periodontal in situ gel. Int J Pharm Investig 3, 29-41, 2013.

15. Moemen D, Bedir T, Awad EA, Ellayeh A. Fungal keratitis: Rapid diagnosis using methylene blue stain. EJBAS doi:10.1016/j. ejbas.2015.08.001, 2015.

16. Kumar R, Sinha VR. Preparation and optimization of voriconazole microemulsion for ocular delivery. Colloids Surf B Biointerfaces 117, 82-88, 2014.

17. Qian $Y$, Wang F, Li R, Zhang $Q, X u$ Q. Preparation and evaluation of in situ gelling ophthalmic drug delivery system for methazolamide. Drug Dev Ind Pharm 36(11), 1340-1347, 2010.

18. Efron N, Young G, Brennan NA. Ocular surface temperature. Curr Eye Res 8, 901-906, 1989.

19. Rathore KS, Nema RK, Sisodia SS. Preparation and characterization of timolol maleate ocular films. J Pharm Tech Res 2(3), 1995-2000, 2010.

20. Clinical and Laboratory Standards Institute. Reference method for broth dilution antifungal susceptibility testing of filamentous fungi; approved standard CLSI document M38-A2. Clinical and Laboratory Standards Institute, Wayne, PA, 2008.

21. Clinical and Laboratory Standards Institute. Reference method for broth dilution antifungal susceptibility testing of yeasts. Approved Standard M27-A3. Clinical Laboratory Standards Institute Wayne, PA. 2009.

22. Ansari Z, Miller D, Galor A. Current thoughts in fungal keratitis: diagnosis and treatment. Curr Fungal Infect Rep 7, 209-218, 2013.

23. Shukla SH, Kumar M, Keshava GBS. Mycotic keratitis: an overview of diagnosis and therapy. Mycoses 51, 183-199, 2008.
24. Borole PM, Chaudhari YS, Dharashivkar SS, Kumavat SD, Shenghani K, Shah PR. Preparation and evaluation of in situ gel of levofloxacin hemihydrate for treatment of peridontal disease. IJPRBS 2(3), 185-196, 2013.

25. Dumortier G, Grossiord JL, Agnely F, Chaumeil JC. Review of Poloxamer 407 Pharmaceutical and Pharmacological Characteristics. Pharm Res 23, 2709-2728, 2006.

26. Gonnering R, Edelhauser HF, Van Horn DL, Durant W. The pH tolerance of rabbit and human corneal endothelium. Invest Ophthalmol 18, 37390, 1979.

27. Üstündağ-Okur N, Gökçe EH, Boybıyık DI, Eğrilmez S, Özer Ö, Ertan G. Preparation and in vitro-in vivo evaluation of ofloxacin loaded ophthalmic nano structured lipid carriers modified with chitosan oligosaccharide lactate for the treatment of bacterial keratitis, Eur $\mathrm{J}$ Pharm Sci 2014; 63: 204-215.

28. Mandal S, Thimmasetty MKMJ, Prabhushankar GL, Geetha MS. Formulation and evaluation of an in situ gel-forming ophthalmic formulation of moxifloxacin hydrochloride. Int J Pharm Investig 2(2), 78-82, 2012.

29. Espinel-Ingroff A, Johnson E, Hockey H, Troke P. Activities of voriconazole, itraconazole and amphotericin $B$ in vitro against 590 moulds from 323 patients in the voriconazole Phase III clinical studies. J Antimicrob Chemother 61, 616-620, 2008.

30. Araujo R, Pina-Vaz C, Rodrigues AG. Susceptibility of environmental versus clinical strains of pathogenic Aspergillus. Int $J$ Antimicrob Agents 29, 108-111, 2007.

31. Arikan S, Sancak B, Alp S, Hascelik G, Mcnicholas P. Comparative in vitro activities of posaconazole, voriconazole, itraconazole, and amphotericin B against Aspergillus and Rhizopus, and synergy testing for Rhizopus. Med Mycol 46, 567-573, 2008.

32. Pfaller MA, Diekema DJ, Rinaldi MG, Barnes R, Hu B, Veselov AV, Tiraboschi N, Nagy E, Gibbs DL. Results from the ARTEMIS DISK global antifungal surveillance study: a 6.5-year analysis of susceptibilities of candida and other yeast species to fluconazole and voriconazole by standardized disk diffusion testing. J Clin Microbiol 43(12), 5848-5859, 2005.

Received : 31.01.2016

Accepted : 24.03.2016 